\title{
GMR
}

\section{Genetic diversity analyses of tropical goats from some countries of Middle East}

\author{
R.M. Al-Atiyat ${ }^{1,2}$ \\ ${ }^{1}$ Animal Production Department, King Saud University, Riyadh, \\ Kingdom of Saudi Arabia \\ ${ }^{2}$ Department of Animal Production, Mutah University, Mutah, Karak, Jordan \\ Corresponding author: R.M. Al-Atiyat \\ E-mail: ralatiyat@ksu.edu.sa / ratiyat@mutah.edu.jo
}

Genet. Mol. Res. 16 (3): gmr16039701

Received April 17, 2017

Accepted July 3, 2017

Published July 28, 2017

DOI http://dx.doi.org/10.4238/gmr16039701

Copyright (C) 2017 The Authors. This is an open-access article distributed under the terms of the Creative Commons Attribution ShareAlike (CC BY-SA) 4.0 License.

\begin{abstract}
The genetic structure of 10 goat breeds from four countries of the Middle East and Horn of Africa was investigated at 17 microsatellite loci. The average allele number and richness were 9.65 and 5.78, respectively. The mean expected heterozygosity per population was $0.703,0.715,0.719,0.699,0.749,0.719,0.731,0.721$, 0.719, and 0.730 for Somali from Somalia, Tohami, Bishi, Jabali, Ardi, and Saudi Damascus from Saudi Arabia, Black Bedouin, Sahrawi, and Jordanian Damascus from Jordan, and Syrian Damascus from Syria. The low level of genetic differentiation across large topographic features was expressed by pairwise difference coefficient $\left(F_{\mathrm{ST}}=0.001-\right.$ 0.135). The goats were assigned to four genetic pools, indicating the occurrence of gene flow within a potential genetic exchange network. The genetic exchange possibly occurred in the past when the ancient trade routes - Incense and Pilgrimage Routes - were active in these countries. Despite the distances far by thousands of kilometers or separated by the boundaries, Saudi goats kept a reasonable level of admixture, indicating common ancestry. These results are in agreement with a known history of the goat populations in regards to geographical
\end{abstract}

Genetics and Molecular Research 16 (3): gmr16039701 
location and evolutionary time of past common ancestors. Further study is recommended considering goats from other Middle East countries.

Key words: Capra hircus; Gene flow; Admixture; Geographical and breeding isolation

\section{INTRODUCTION}

A discussion was centered on whether livestock populations in the tropics had a substantial level of genetic variation (Galal, 2005). Furthermore, reports were questioning the genetic structure and admixture of tropical goat populations along with genetic diversity (Ajmone-Marsan et al., 2014). It is known that the goats in the tropics and subtropics have a substantial level of genetic variation, whereas limited variation in temperate goats was reported (Cañón et al., 2006). The best explanation, for the case of the temperate goats, might be related to limited allele diversity that is related to small sample size and artificial selection in favor of economic traits. On the other hand, these reasons were not matching the case of tropical goats, which are found in a large and naturally selected sample size (Kim et al., 2016). As a consequence, it is expected to express high genetic and/or allelic diversity in the tropical goat than the temperate goats. Therefore, genetic diversity and structure of tropical goats need more investigation and clarification. In this regard, genetic diversity of goats of some Arab countries such as Somalia, Saudi Arabia, Jordan, Syria, and Egypt were earlier investigated in different studies considering tropical and subtropical conditions and production systems with no selection practices (Cañón et al., 2006; Agha et al., 2008; Aljumaah et al., 2012; Al-Atiyat and Aljumaah, 2014; Al-Atiyat et al., 2015a,b; Elbeltagy et al., 2016). In general, the studies reported a high genetic diversity of the goat within their own country or in a comparison to those of temperate countries. However, no study discussed the possible reason for such phenomenon in tropical countries. Particularly, Arab countries characterized by hot and dry conditions over topography ranging from barren deserts to less vegetative hills and mountains. The countries with shared borders have experienced different animal exchange networks (Cañón et al., 2006).

The animal exchange networks have reshaped the genetic structure of many livestock from Eurasia to Africa (Tapio et al., 2010; Warmuth et al., 2013; Elbeltagy et al., 2015; Gaouar et al., 2015). Knowledge of historical animal exchange in the Arab world indicated that some countries have been the region of exchange from ancient times until recent times (Warmuth et al., 2013). The main route was the central Arabian Desert route (Incense Route - South-North of Arab world) of goods traveled from Southern Arabia (currently Somalia or Yemen) through the Arabian Peninsula (currently Saudi Arabia) and Damascus region (currently Jordan and Syria) to the Phoenicians on the Mediterranean Sea (Liu, 2010). On the other hand, there was a Pilgrimage Route that Muslims traveled across the globe (North-South) to reach Islam's two holiest cities - Mecca and Medina - in the Hejaz region of Saudi Arabia (Almathen et al., 2016). Thus, Saudi Arabia exposed to animal exchange network in the past while people traveled by and/or with the animals for trading or worship purposes. These two routes were connected to the Silk Road (East-West route), the oldest continuous exchange networks in history as early as the second millennium B.C. (Christian, 2000).

During the Ottoman Empire, the goats of Jordan and Syria were moving up to the south-eastern and even eastern part of Turkey namely Diyarbakir (Porter, 2002). Furthermore,

Genetics and Molecular Research 16 (3): gmr16039701 
there has always been smuggling of sheep and goats from Turkey to Arabian Peninsula via Syria and Iraqi until very recent years. This allowed great mixing of goat breeds of nearby countries with those locals of each country. For instance, Damascus breed being a milk breed has always been used as a sire breed for improving the milking ability of the local herds composed of lower milking breeds in Fertile Crescent and Arabian Peninsula regions (Al-Atiyat and Aljumaah, 2014). In the present time, Saudi Arabia is importing a livestock, including goats, from all over the world - like Somali goat of Somalia - for local consumption and slaughtering during the religious feast, Eid Al-Adha. In addition, Damascus goats of Syria and Cyprus were imported for milk consumption and beauty shows utilizing them either through pure breeding or crossbreeding strategy (Gordin, 1980). As a consequence, the animal exchange network of the past and the present might have been shaped the genetic structure of current goat populations reared in the countries where those routes crossed in the past. In this study, we investigated the population genetic diversity and structure of the goats in four tropical Arab countries featured by the goat exchange networks, topographical landscape and separated by thousands of kilometers and political boundaries.

\section{MATERIAL AND METHODS}

\section{Goat populations and sampling}

The populations were Somali from Somalia, Tohami, Bishi, Jabali, Ardi, and Saudi Damascus from Saudi Arabia, Black Bedouin (Dhaiwi), Sahrawi (Desert), and Jordanian Damascus (Shami) from Jordan, and Syrian Damascus from Syria (Figure 1). All populations are indigenous to the country except the Damascus goats sampled from Saudi Arabia and Jordan. The Saudi Damascus goats were exotic imported mainly from Syria, whereas the Jordanian Damascus goats in this study were originally imported from Cyprus. The sampling size was 11, 22, 33, 29, 18, 10, 12, 13, 9, and 13 unrelated kids of Somali, Tohami, Bishi, Jabali, Ardi, Black Bedouin, Sahrawi, Saudi Damascus, Jordanian Damascus, and Syrian Damascus populations, respectively. The total sample number was 170 mature unrelated male kids chosen randomly from different herds and different common rearing regions in each country. The Somali goats were mature unrelated male kids sampled from the sale yard in the Saudi Arabia and raised under an extensive system in Somalia. The sample size of each population was determined in as possible to represent the pure animal and to reflect the population size in the geographical region and/or country considering the origin and the source. The study area represented regions belonging to subtropics; Near East (Syria and Jordan), and tropics; Arabian Peninsula (Saudi Arabia) and Horn of Africa (Somalia). The ten goat populations sampled from these countries classified as tropical and subtropical countries because of the location in geographic and climate zones of the tropics of Scorpion and Capricorn. The subtropical climate of Jordan and Syria is often characterized by warm to hot summers and cool to mild winters with infrequent frost. The Somali, Tohami, Bishi, and Jabali populations were representing goats of the tropical region, which reared under humid conditions most of the year. The Ardi, Sahrawi, and Black Bedouin were reared in deserts with dry and hot climate over the year. Finally, the Damascus goats of the three countries were reared under the sedentary system in which rearing conditions mimic moderate climate conditions. The blood sampling and animal handling protocol were approved by the Animal Ethics Committee at King Saud University (Permission No. RG-1435-064). The blood was taken from the jugular vein

Genetics and Molecular Research 16 (3): gmr16039701 
using a vacutainer method where anticoagulated whole blood collected in EDTA-containing tubes. The collected blood samples were transferred to an icebox and refrigerated until DNA extraction was performed in next day. The blood samples were subjected to DNA extraction using DNA extraction available commercial kits of Amersham Biosciences ${ }^{\circledR}$. The DNA was then quantified and purified using a Nano-Drop ${ }^{\circledR}$ DNA spectrophotometer considering the $\mathrm{A}_{260} / \mathrm{A}_{280}$ absorbance ratio. Finally, the DNA concentration was adjusted to $10 \mathrm{ng} / \mu \mathrm{L}$ for DNA genotyping.

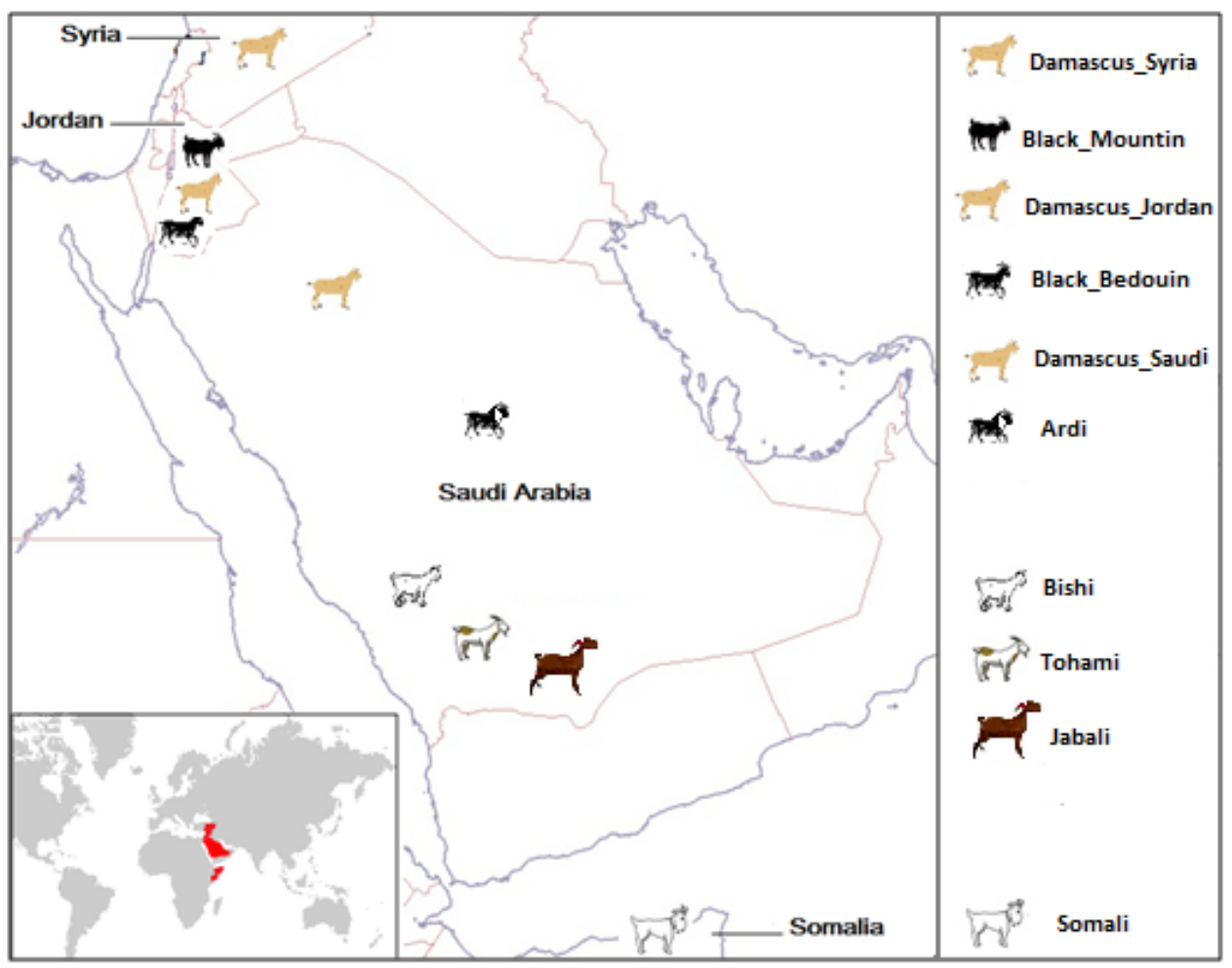

Figure 1. Sampling location of the ten goat breeds in the countries of the study; Somalia, Saudi Arabia, Jordan, and Syria.

\section{Genotyping and fragment analyses}

Seventeen microsatellite (MS) markers recommended by the International Society for Animal Genetics (ISAG) (FAO, 2011) were used for genotyping reactions by PCR (Table 1). The PCR amplification was performed using a GeneAmp ${ }^{\circledR}$ PCR system 9700. The PCR mixture was made according to recommended protocols (Green and Sambrook, 2012). It consists of $10 \mu \mathrm{L}$ PCR master mix, $2 \mu \mathrm{L}$ forward and reverse fluorescently labeled MS primers; $1 \mu$ LDNA template and double-distilled water was added to make up the final volume of $20 \mu \mathrm{L}$ for each reaction. The PCR cycling program of 35 cycles was then applied as an initial denaturing step at $95^{\circ} \mathrm{C}$ for $5 \mathrm{~min}$, followed by a denaturation step at $95^{\circ} \mathrm{C}$ for $45 \mathrm{~s}$, then 
annealing step, according to each primer's recommended temperature for $1 \mathrm{~min}$ and followed by a final temperature as extension at $72^{\circ} \mathrm{C}$ for $1 \mathrm{~min}$. They were repeated for amplification. Then, a final extension at $72^{\circ} \mathrm{C}$ for 10 min was included. The resulted PCR products were performed on ABI Prism LIZ-500. The raw data were representing allele sizes for each marker that was immediately visualized, scored, and then saved in a specific file format using the GeneMapper ${ }^{\circledR}$ software, version 4.0; Applied Biosystems ${ }^{\circledR}$.

\section{Genetic data analysis}

The number of alleles $\left(N_{\mathrm{A}}\right)$, allelic richness $\left(A_{\mathrm{R}}\right)$, and expected heterozygosity - gene diversity $\left(H_{\mathrm{E}}\right)$ at each studied MS locus and population were estimated using the FSTAT software, version 2.9.3 (Goudet, 1995). The reason of using the STAT software version 2.9.3 was to overcome any possible bias in the results due to the different sample size in the studied populations according to Leberg (2002). The hierarchical genetic diversity and analysis of molecular variance (AMOVA) including $F$-statistics coefficients [pairwise difference coefficient $\left(F_{\mathrm{ST}}\right)$ and intra-population differentiation $\left(F_{\text {IS }}\right)$ ] were computed under HardyWeinberg equilibrium (HWE) using the ARLEQUIN genetic software, version 3.5 (Excoffier and Lischer, 2010). On the other hand, genetic distance (D) matrix between populations was measured using the Genetic Data Analysis software, version 1 (Weir, 1996), which utilizes the most widely used measure of genetic distances proposed by Nei (1972). Evolutionary distance phylogeny was drawn from the matrix using the MEGA5 software, version 5 (Tamura et al., 2011). The population structure was analyzed using the STRUCTURE software, version 2.3.4 (Pritchard et al., 2000) considering an admixture model and correlated allele frequencies between studied breeds. The length of the burn-in Monte Carlo Markov chain (MCMC) were 200,000 and 100,000 in 10 runs for the possible number of clusters $(\mathrm{K})$ from 2 to 10 . For each $\mathrm{K}$ value, log probability of Delta $(\mathrm{L}[\mathrm{K}])$ and $F_{\mathrm{ST}}$ values for each cluster were estimated. The results were then exported into STRUCTURE HARVESTER (Earl and von Holdt, 2012) for plotting the likelihood membership coefficient (Delta K) values for the most likely number of clusters or genetic pools.

\section{RESULTS}

The total number of alleles and $N_{\mathrm{A}}$ of per locus were 155 and 9.1, respectively (Table 1). The mean $N_{\mathrm{A}}$ for all populations was 5.5 alleles, whereas it was $4.9,5.4,6.6,5.9,6.0,5.4$, 5.5, 5.1, 4.5, and 5.4 for each of Somali, Tohami, Bishi, Jabali, Ardi, Black Bedouin, Sahrawi, Saudi Damascus, Jordan Damascus, and Syrian Damascus goats, respectively (Table 1). Thus, the highest mean $N_{\mathrm{A}}$ was in the Bishi goat (6.6), while it was (8.1) at ILSTS029, which showed the highest total number of alleles (14) (Table 1). The lowest $N_{\mathrm{A}}$ value (2) was found at different loci in the Tohami, Bishi, Jabali, and Black Bedouin. In general, locus OARFCB20 exhibited the highest $N_{\mathrm{A}}(12)$ in the Bishi population. The variation in the sample size of the population might bias the resulted $N_{\mathrm{A}}$ values. Alternatively, another genetic measure of allelic diversity, $A_{\mathrm{R}}$, was considered. The mean $A_{\mathrm{R}}$ per locus was 5.78 alleles (Table 1). It was 4.7, 4.6, 4.9, 4.7, 5.3, 5.1, 4.9, 4.6, 4.4, and 4.8 for Somali, Tohami, Bishi, Jabali, Ardi, Black Bedouin, Sahrawi, Saudi Damascus, Jordan Damascus, and Syrian Damascus goats (Table 1). Thus, the highest mean $A_{\mathrm{R}}$ was in the Ardi population, whereas the highest $N_{\mathrm{A}}$ was in the Bishi. In addition, $A_{\mathrm{R}}$ showed a similar trend of the results to $N_{\mathrm{A}}$ at same loci. For example, ILSTS029 showed the

Genetics and Molecular Research 16 (3): gmr16039701 
highest mean value and, in most cases, exhibited the highest $A_{\mathrm{R}}$ in all populations. Generally, the mean $A_{\mathrm{R}}$ ranged from 4.4 (Jordanian Damascus) to 5.3 (Ardi).

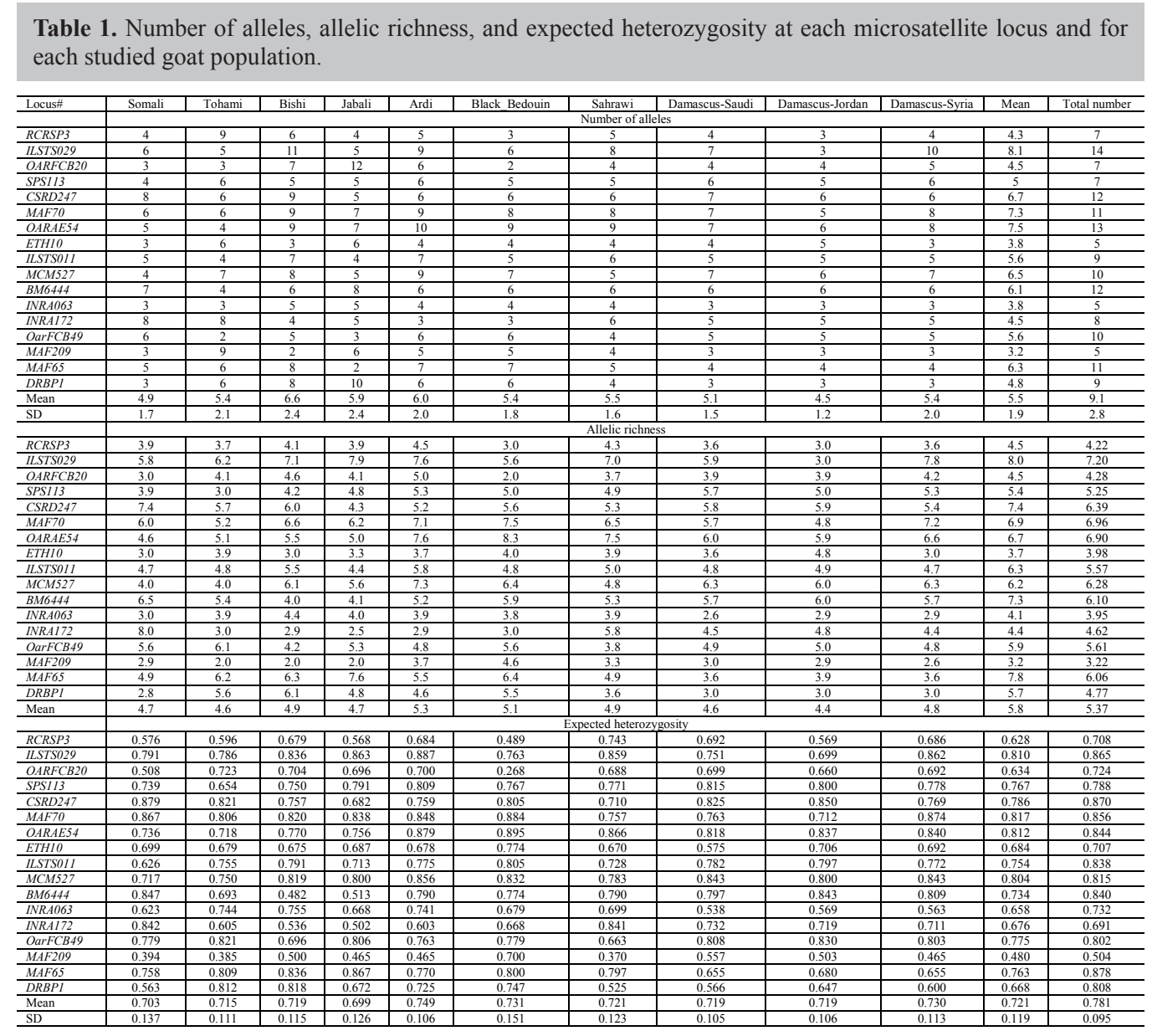

The mean $H_{\mathrm{E}}$ per population was $0.703,0.715,0.719,0.699,0.7490,0.731,0.721$, $0.719,0.719$, and 0.730 for Somali, Tohami, Bishi, Jabali, Ardi, Black Bedouin, Sahrawi, Saudi Damascus, Jordan Damascus, and Syrian Damascus, respectively (Table 1). The results showed high $H_{\mathrm{E}}$ in all studied populations over the 17 MS loci. Overall, the mean $H_{\mathrm{E}}$ at the studied MS loci showed a limited range from 0.699 to 0.749 , reflecting a small range of differences between the values for the studying populations. The results also showed that the highest $H_{\mathrm{E}}$ was observed in Ardi goat, indicating most genetically varied population. Nevertheless, results showed that each population had reasonably good within-genetic variation. AMOVA estimated $8.35,7.24$, and $84.4 \%$ genetic variation between the populations, among the individuals within the populations, and within the individuals, respectively. It was interesting that the level of genetic differentiation between populations had a small value $(8.35 \%)$. This result

Genetics and Molecular Research 16 (3): gmr16039701 
was expressed in values of the genetic differentiation coefficients (Table 2). The $F_{\text {IS }}$ showed a significant positive value of the four indigenous Saudi goat populations: Tohami, Bishi, Jabali, and Ardi (Table 2). The results indicated a shortage of heterozygotes than expected at HWE. The non-significant $F_{\text {IS }}$ values were observed in the other populations. The goats of Jordan and Syria had negative values. The negative values of $F_{\text {IS }}$ were indicating more heterozygosity than expectation at HWE in those populations (Table 2). On the other hand, the $F_{\mathrm{ST}}$ values, pairwise difference coefficients, were found significant in all populations except Damascus goats of Saudi and Syria (Table 2). The $F_{\mathrm{ST}}$ values for each pair of populations varied from the lowest (0.001) between the Saudi Damascus and Syrian Damascus to the highest value (0.135) between the Jabali goats and the Sahrawi (Table 2). The latter indicated these two populations were the most differentiated populations. After that, Somali goat and the Saudi Damascus goats were clearly differentiated. Overall, the Jabali goat of Saudi Arabia was the most differentiated population of the goats of Jordan and Syria. Furthermore, the pairwise genetic distances showed - as expected - the shortest within Damascus goat populations (Table 2 ). The results also showed that the genetic distance between the Ardi goats and the Sahrawi goats was relatively short 0.127 (Table 2). The distances between the Ardi and those of Jordan and Syria were less substantial (0.124-0.367) than those of the Saudi and Somali populations (0.372-0.401).

Table 2. Average number of pairwise differences $\left(F_{\mathrm{ST}}\right)$ (below the diagonal) and genetic distances (D) (above the diagonal) and inbreeding coefficients $\left(F_{\text {IS }}\right)$ for the goat populations.

\begin{tabular}{l|c|c|c|c|c|c|c|c|c|c}
\hline & Somali & Tohami & Bishi & Jabali & Ardi & Black Bedouin & Sahrawi & Damascus-Saudi & Damascus-Jordan & Damascus-Syria \\
\hline Somali* & $\mathbf{0 . 0 2 0}$ & 0.213 & 0.304 & 0.300 & 0.401 & 0.415 & 0.420 & 0.545 & 0.332 & 0.419 \\
\hline Tohami & 0.060 & $\mathbf{0 . 2 4 0}$ & 0.184 & 0.157 & 0.382 & 0.361 & 0.353 & 0.350 & 0.235 & 0.253 \\
\hline Bishi & 0.079 & 0.058 & $\mathbf{0 . 1 4 3}$ & 0.080 & 0.372 & 0.316 & 0.401 & 0.458 & 0.355 & 0.365 \\
\hline Jabali & 0.087 & 0.055 & 0.028 & $\mathbf{0 . 1 2 6}$ & 0.376 & 0.459 & 0.482 & 0.450 & 0.446 & 0.354 \\
\hline Ardi & 0.095 & 0.103 & 0.101 & 0.105 & $\mathbf{0 . 0 7 0}$ & 0.214 & 0.127 & 0.177 & 0.282 & 0.102 \\
\hline Black_Bedouin & 0.117 & 0.104 & 0.092 & 0.129 & 0.063 & $\mathbf{- 0 . 0 4 8}^{\mathrm{NS}}$ & 0.232 & 0.367 & 0.124 & 0.259 \\
\hline Black_Mountin & 0.111 & 0.105 & 0.112 & 0.135 & 0.042 & 0.074 & - & 0.283 & 0.173 & 0.210 \\
\hline Damascus_Saudi & 0.134 & 0.104 & 0.125 & 0.130 & 0.057 & 0.104 & 0.088 & $\mathbf{- 0 . 0 0 1}^{\mathrm{NS}}$ & 0.081 & $0.002^{\mathrm{NS}}$ \\
\hline Damascus_Jordan & 0.102 & 0.078 & 0.103 & 0.131 & 0.082 & 0.043 & 0.059 & 0.029 & $\mathbf{- 0 . 0 6 1}^{\text {NS }}$ & 0.075 \\
\hline Damascus_Syria & 0.105 & 0.078 & 0.104 & 0.106 & 0.034 & 0.078 & 0.067 & $0.001^{\mathrm{NS}}$ & 0.003 & $\mathbf{- 0 . 0 1 0}^{\mathrm{NS}}$ \\
\hline
\end{tabular}

*All values were significant $(\mathrm{P}<0.05)$, except those with NS (non-significant).

The constructed phylogenetic tree revealed the differentiations between the populations. As seen in Figure 2, Saudi populations were clustered in one group close to the Somali goats. It was notable that the Ardi from Saudi Arabia was clustered with the Sahrawi from Jordan. On the other hand, the Black Bedouin from Jordan was far from all populations and clustered alone. Definitely, all Damascus populations were, as expected, clustered together.

Finally, the results revealed that the highest delta- $K(\ln \operatorname{Pr}(X \mid K))$ occurs at $K=4$ (Figure 3). Thus, the best number of possible clusters of the present 10 goat populations was four. In more details, the results indicated that Delta $\mathrm{K}$ of the bootstrap samples determined the potential of ancestral populations at $\mathrm{K}=4$ (Figure 3).

As a consequence, the genetic structure of the ancestral population presented each individual of the 10 populations by a single vertical line broken into the four color segments (Figure 4). The mixed colors with lengths proportional represent the admixture level of the predefined populations of the four assumed populations. The results declared that the studied populations were better defined as they belong to four genetic pools instead of the 10 populations. In other words, the results stated that there were most probably four common 
ancestry populations for the present populations (Figure 4). The first genetic pool allocated Somali and Tohami populations. The second pool had both Jabali and Bishi populations. The third genetic pool allocated the Ardi, Black Bedouin, and Sahrawi. The last genetic pool had all Damascus populations (Figure 4). However, the genetic admixture was more noted for the individuals of Bishi and Jabali from Tohamai and Somali and vice versa. Furthermore, few individuals of Ardi and Black Bedouin had a good proportion of admixture coming from the Damascus goats. A similar situation of admixture proportion was also shown in the other populations.

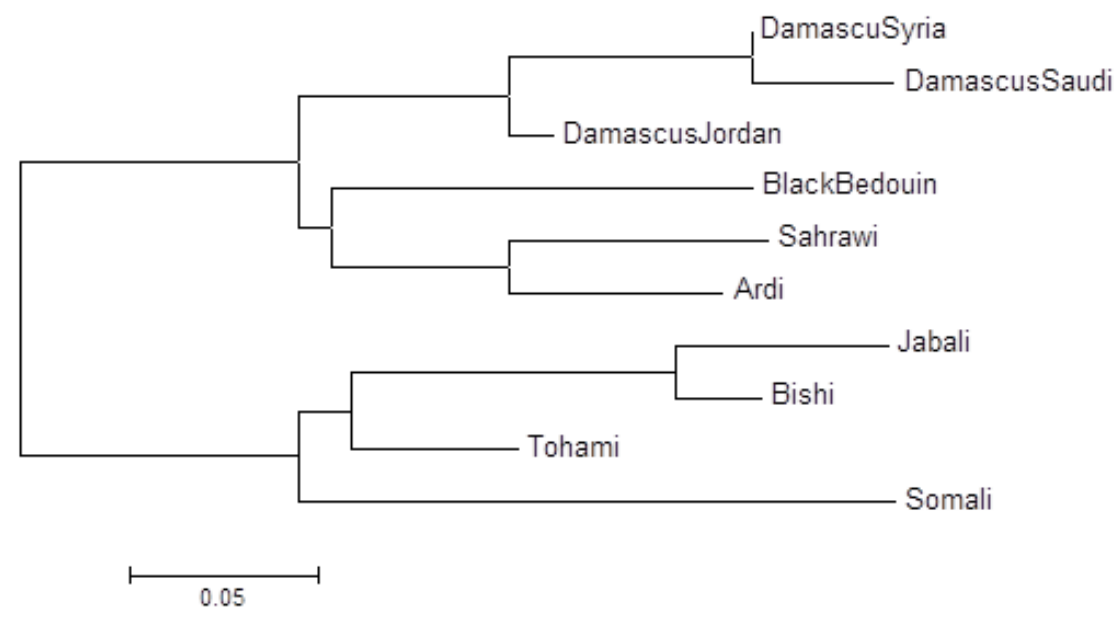

Figure 2. Neighbor joining tree representing the evolutionary relationships of the ten goat populations.

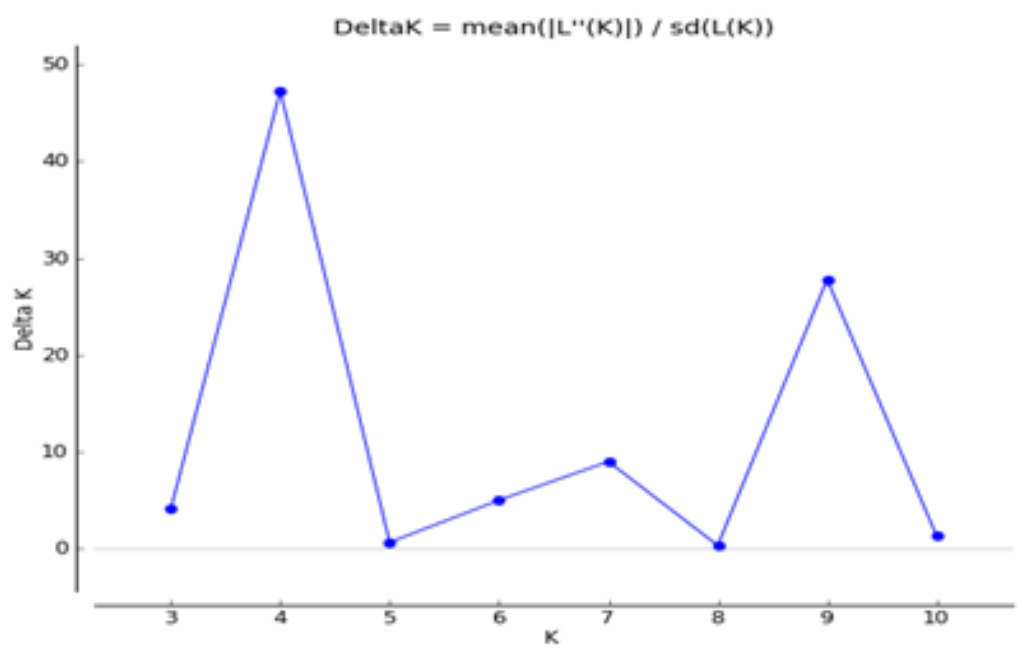

Figure 3. Plot of data likelihoods for several values of mean Delta $\mathrm{K}$ values and $\mathrm{K}$ from 3 to 10 .

Genetics and Molecular Research 16 (3): gmr16039701 


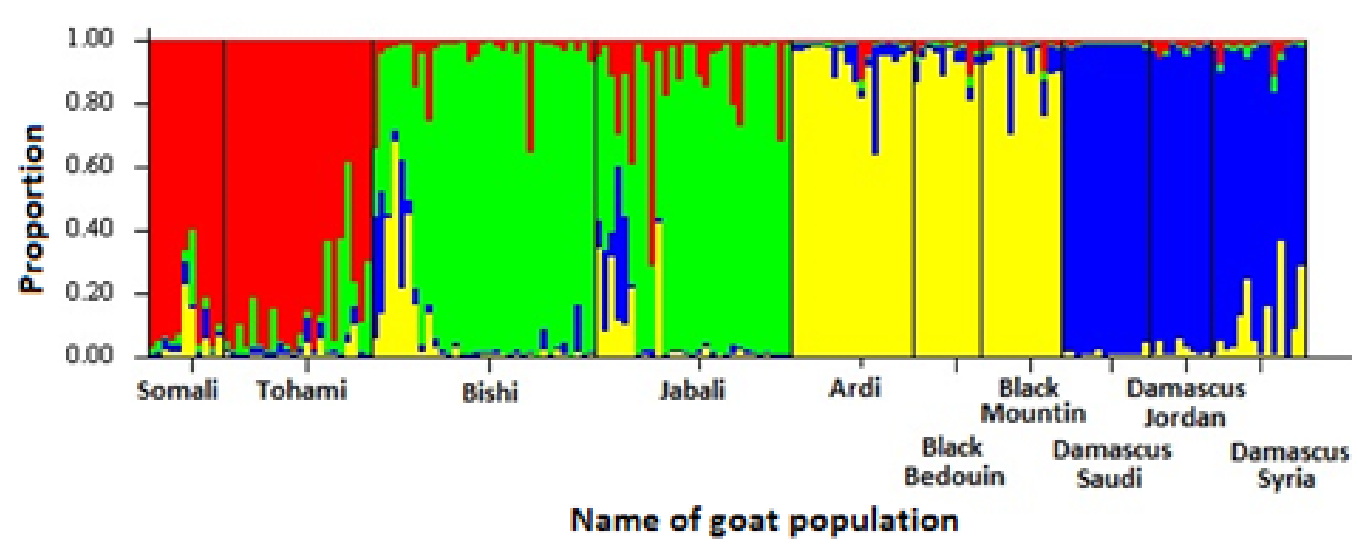

Figure 4. Estimated population structure for each individual represented by a single vertical line broken into K colored segments, with lengths proportional to four genetic pools.

\section{DISCUSSION}

It was worth mentioning, at the beginning, that the high genetic variation observed within the goat populations was indicated by high $N_{\mathrm{A}}, R_{\mathrm{A}}$, and $H_{\mathrm{E}}$. The allelic diversity measured by both $N_{\mathrm{A}}$ and $R_{\mathrm{A}}$ estimates was high. Furthermore, a little variation in the number of alleles (reflecting limited rich allele size) was observed for those populations. The $N_{\mathrm{A}}$ values considered very close to the $A_{\mathrm{R}}$ values for most of studied loci and populations. On the other words, the result might indicate that both estimates have shown no differences due to the variation in sampling size. In literature, more $N_{\mathrm{A}}$ (7-31) was reported in the Southern Indian goat breed in which $N_{\mathrm{A}}$ (Dixit et al., 2010) and close values of the $N_{\mathrm{A}}(5-6)$ was observed in the Egyptian goats (Agha et al., 2008; Elbeltagy et al., 2016). In addition, Chinese goat breeds showed a limited range from 5.24 to 7.77 alleles (Li et al., 2002). Finally, in previous studies on some of the studied breeds, the $N_{\mathrm{A}}$ was more than 5 alleles in different Saudi goat populations (Aljumaah et al., 2012; Al-Atiyat et al., 2015b) and around 6.9 in different Jordan goat breeds (Al-Atiyat et al., 2015a). This difference might be due to differences in breeds and the number and type of MS markers. Furthermore, the results of $H_{\mathrm{E}}$ suggested that all populations had a considerable high amount of genetic diversity $(>0.69)$. In previous reports, $H_{\mathrm{E}}$ of Saudi Ardi, Jabali, Bishi, and Tohami goats ranged from 0.675 to 0.71 (Cañón et al., 2006; Aljumaah et al., 2012; Al-Atiyat et al., 2015b). Similarly, values of $H_{\mathrm{E}}$ were 0.67 in Gohilwdi Indian (Fatima et al., 2008), 0.71 in the Namibian (Els et al., 2004), 0.676, 0.76, and 0.735 in the Jordan Black Bedouin, Sahrawi, and Jordan Damascus, respectively (Al-Atiyat et al., 2015a). In contrast, Kanniadu Indian goat showed higher $H_{\mathrm{E}}$ values (0.98) (Thilagam et al., 2006), whereas some breeds showed lower $H_{\mathrm{E}}$ values - South African goat (0.46) (Visser et al., 2004). Overall, goat populations of the present study had similar genetic parameters of within diversity to those found in the study of the tropical goat populations from many countries (Cañón et al., 2006). The high level of the within genetic variation estimates found in the present study could be due to traditional breeding practices performed by farmers and or due to natural selection of the tropical conditions. The breeding practices by the farmer of keeping most tolerable were the more likely reason to explain the genetic variation in the tropics. Overall, high within genetic 
variation might reflect better adaptation to tropical conditions and topography. For example, the Jabali goats, the least varied population, are raised in the southern Saudi mountains, whereas the Ardi goats, the most varied population, are raised in the deserts. The geographical features of mountains provide isolation in which alleles maintained and thus less variation expected (Taylor et al., 1993). The deserts in which Ardi, Sahrawi, and Black Bedouin raised, allow for genetic migration between herds considering common extensive production systems. Gene flow among most goat breeds has probably been restricted or facilitated by geographical features (Cañón et al., 2006).

The $F_{\text {IS }}$ were noticeably varied from -0.061 in the Jordanian Damascus to 0.243 in the Tohami goats. In a comparison with other studies of the Saudi goats, the $F_{\text {IS }}$ values were reported for Bishi (0.114) and Jabali (Najarani) (0.123) goats (Cañón et al., 2006) and for Saudi Ardi goat (0.18) (Aljumaah et al., 2012). The positive $F_{\text {IS }}$ values indicate that individuals in a population are more related and/or they have the heterozygote deficiency, while the negative $F_{\text {IS }}$ indicates that individuals are less related than expected under a model of random mating (Hedrick, 2000). The overall $F_{\text {IS }}$ value for Somali and Saudi populations were positive, indicating a certain level of heterozygote deficiency. The potential reasons for such findings could be due firstly to a Wahlund effect when population subdivision occurred. Tohami population was sampled from a different smaller population in several regions of the southern region of the Saudi Arabia. The second potential reason might be using a small number of breeding males or mating had been occurring among closely related animals, the case we observed mainly in Bishi and Jabali herds. In Somali population, the sampled male kids might have produced by the mating of related parents of the same flock. Finally, the remaining goat populations showed an excess of heterozygosity and had outbreeding individuals, in particular, Damascus goats of all countries. The reason is definitely that the gene flow of male Damascus was imported directly from Syria or indirectly from Cyprus through Jordan (Ridley, 2004).

AMOVA results demonstrated that only $8.35 \%$ of the total genetic variation could be attributed to the difference between the studied populations. In an agreement, Al-Atiyat and Aljumaah (2014) reported that $6.0 \%$ of total genetic variation was due to population variation of Ardi, Damascus, and Black Bedouin goats. The geographical partitioning study of goat diversity in Europe and the Middle East stated that $7 \%$ of the total genetic variation was explained by a difference between goat breeds (Cañón et al., 2006). The most differentiated populations in the present study were Somali and Jabali goats. The results of the Somali goats are expected, from the geographical aspect, to be genetically distinct from the other studied populations. In details, Somali goat had low values with Tohami $(0.06)$, which is the most geographically closed and raised in the same geographical features and conditions. Somali goat was reported to be introduced into Arabian Peninsula long time ago (Tucho, 2004). In earlier studies, Saudi Najrani (Jabali) and Beechi (Bishi) goats had a closer value of $F_{\text {ST }}$ (0.078) (Cañón et al., 2006). The resultant low differentiation level corresponds to historical gene flow across the regions considering the past effect of network exchange of ancient routes and current effect of goat trading and imports.

The genetic distance estimates revealed another angle to look at the genetic relationship between the populations. The short genetic distance $(0.080)$ between Jabali and Bishi populations and the longest genetic distance (0.420) between Jabali and Sahrawi were indications that geographically closer population, the genetically close. The result of the dendrogram tree in the present study clustered the goats into two groups. The first group formed one clade of Somali population alone and the three Saudi goat populations of the

Genetics and Molecular Research 16 (3): gmr16039701 
southern region. It is clear again that geographically closer population, the genetically close. On the other hand, the second group had Saudi Ardi along with Sahrawi indicating their common genetic ancestry and being under same living conditions of deserts and might be experiencing same breeding practices. Finally, in the same second group, all Damascus goats were in a clade indicating that they had the same genetic origin. However, Black Bedouin was out of this clade, but in the same group. This finding was expected because Black Bedouin goat dominates the herds of Bedouins in the deserts of the Middle East (Gordin, 1980). The Jabali and Bishi breeds were studied earlier and reported to be very close to the same cluster and away from 43 goat breeds from the Middle East and Europe (Cañón et al., 2006). Finally, the Somali as an exotic and Tohami goat had close genetic relationships confirming results of an earlier report (Tucho, 2004) that states that Tanami was genetically closer to African and Ethiopian goat breeds. In summary, our results proved that the three Saudi goats - Bishi, Jabali, and Ardi - have descended from a common ancestor sometime in the past and related to those of the Levant countries. The information about the Damascus goat in the region proved that goat genetic exchange took place in the present times for many purposes such as producing more milk and meat throughout pure breeding or crossbreeding programs and beauty shows.

The Bayesian test of the population structure analysis identified four main genetic pools underlying the ancestral genetic diversity. It is clear that common genotypes of the individuals helped in grouping the populations into the four genetic pools. However, some individuals of each genetic pool had admixture level with the other genetic pools. In particular, the Saudi populations had more admixture proportions. The admixture between the Jabali and Bishi might be shared from the Tohami population of the first genetic pool. The same can be said to Ardi that showed admixture with the fourth genetic pool of Damascus goat. Amazing that within the fourth genetic pool, the Damascus goat of Syria had more admixed individuals than the Damascus goat sampled from Saudi and Jordan. The explanation might be that the Syrian Damascus goat reserved more of ancestry genetic resources. It is worth mentioning that the majority of Damascus goats in Jordan had been imported from Cyprus in the last twenty years. In fact, the Cyprus Damascus goat is originally derived from the Syrian Damascus population (Mavrogenis et al., 2006). The Saudi Damascus goats might be more pure to its unique genetic pool, because of recent selection of unique morphological features and beauty show purposes. However, evidence of genetic migration as a result of recent crossbreeding was also observed between population - particularly Ardi and Damascus - when sampling took place. These potential incidences of gene flow were expecting in the closer regions of the tropics. Similar results were reported for goats of geographically close countries (Cañón et al., 2006; Al-Atiyat and Aljumaah, 2014). Considering different species, similar observations of reshaping genetic structure by genetic network exchange were reported in sheep, camels, and horses, which were better adapted to tropical conditions and deserts and were the means of transport along the ancient routes (Liu, 2010; Warmuth et al., 2013). This study provides good examples about the effectiveness of the animal exchange network in reshaping the genetic structure of goat populations across the different geographical features of the four tropical Arab countries.

\section{CONCLUSION}

High level of genetic diversity and low level of genetic differentiation of the studied goat population were observed. These results might be explained by evidence of historical

Genetics and Molecular Research 16 (3): gmr16039701 
and present gene flow in these populations. The genetic structure was not reshaped by political boundaries or geographical distances. Nevertheless, the animal exchange networks and topography played role in reshaping the genetic structure. The goat exchange networks might highlight the gene flow during the ancient routes in these populations and current goat trading. These results are in agreement with a known history of the populations in regards to their geographical location and their expected evolutionary time of past common ancestors. Indeed, the results might need further justification considering goat populations from the goat Domestication Center - Iraq, Iran, and Turkey - and from countries where Silk Road crossed.

\section{Conflicts of interest}

The author declares no conflict of interest.

\section{ACKNOWLEDGMENTS}

Research supported by the Deanship of Scientific Research at King Saud University under grant of research group \#RG-1435-064.

\section{REFERENCES}

Agha SH, Pilla F, Galal S, Shaat I, et al. (2008). Genetic diversity in Egyptian and Italian goat breeds measured with microsatellite polymorphism. J. Anim. Breed. Genet. 125: 194-200. https://doi.org/10.1111/j.1439-0388.2008.00730.x

Ajmone-Marsan P, Colli L, Han JL, Achilli A, et al. (2014). The characterization of goat genetic diversity: Towards a genomic approach. Small Rumin. Res. 121: 58-72. https://doi.org/10.1016/j.smallrumres.2014.06.010

Al-Atiyat RM and Aljumaah RS (2014). Genetic relatedness between Ardi, Black Bedouin and Damascus goat breeds. Genet. Mol. Res. 13: 4654-4665. https://doi.org/10.4238/2014.June.18.8

Al-Atiyat RM, Tamimi H, Salameh N and Tabbaa MJ (2015a). Genetic diversity and differentiation of Jordan goat breeds using microsatellite markers. J. Anim. Plant Sci. 25: 1532-1539.

Al-Atiyat RM, Alobre M, Aljumaah RS and Alshaikh MA (2015b). Microsatellite based genetic diversity and population structure of three Saudi goat breeds. Small Rumin. Res. 130:90-94. https://doi.org/10.1016/j.smallrumres.2015.07.027

Aljumaah R, Musthafa M, Al-Shaikh M, Badri O, et al. (2012). Genetic diversity of Ardi goat based on microsatellite analysis. Afr. J. Biotechnol. 11: 16539-16545.

Almathen F, Charruau P, Mohandesan E, Mwacharo JM, et al. (2016). Ancient and modern DNA reveal dynamics of domestication and cross-continental dispersal of the dromedary. Proc. Natl. Acad. Sci. USA 113: 6707-6712 https:// doi.org/10.1073/pnas.1519508113.

Cañón J, García D, García-Atance MA, Obexer-Ruff G, et al.; ECONOGENE Consortium (2006). Geographical partitioning of goat diversity in Europe and the Middle East. Anim. Genet. 37: 327-334. https://doi.org/10.1111/ j.1365-2052.2006.01461.x

Christian D (2000). Silk Roads or Steppe Roads? The Silk Roads in world history. J. World Hist. 11: 1-26. https://doi. org/10.1353/jwh.2000.0004

Dixit SP, Verma NK, Aggarwal RAK, Vyas MK, et al. (2010). Genetic diversity and relationship among southern Indian goat breeds based on microsatellite markers. Small Rumin. Res. 91: 153-159. https://doi.org/10.1016/j. smallrumres.2010.02.015

Earl DA and von Holdt BM (2012). STRUCTURE HARVESTER: a website and program for visualizing STRUCTURE output and implementing the Evanno method. Conserv. Genet. Resour. 4: 359-361. https://doi.org/10.1007/s12686-011-9548-7

Elbeltagy AR, Aboul-Naga AM, Hassen H, Rischkowsky, et al. (2015). Genetic diversity and structure in Egyptian indigenous sheep populations mirror patterns of anthropological interactions. Small Rumin. Res. 132: 137-142. https://doi.org/10.1016/j.smallrumres.2015.10.020

Elbeltagy AR, Aboul-Naga AM, Hassen H, Solouma, et al. (2016). Genetic diversity and structure of goats within an early livestock dispersal area in Eastern North Africa. Afr. J. Biotechnol. 15: 431-441. https://doi.org/10.5897/ $\underline{\mathrm{AJB} 2015.14891}$

Genetics and Molecular Research 16 (3): gmr16039701 
Els JF, Kotze A and Swart H (2004). Genetic diversity of indigenous goats in Namibia using microsatellite markers: preliminary results. S. Afr. J. Anim. Sci. 34: 65-67.

Excoffier Land Lischer HEL (2010). Arlequin suite ver 3.5: a new series of programs to perform population genetics analyses under Linux and Windows. Mol. Ecol. Resour. 10: 564-567. https://doi.org/10.1111/j.1755-0998.2010.02847.x

FAO (Food and Agriculture Organization) (2011). Molecular Genetic Characterization of Animal Genetic Resource. Available at http://www.fao.org/docrep/.

Fatima S, Bhong CD, Rank DN and Joshi CG (2008). Genetic variability and bottleneck studies in Zalawadi, Gohilwadi and Surti goat breeds of Gujarat (India) using microsatellites. Small Rumin. Res. 77: 58-64. https://doi.org/10.1016/j. smallrumres.2008.01.009

Galal S (2005). Biodiversity in goats. Small Rumin. Res. 60: 75-81. https://doi.org/10.1016/j.smallrumres.2005.06.021

Gaouar SBS, Da Silva A, Ciani E, Kdidi S, et al. (2015). Admixture and local breed marginalization threaten Algerian sheep diversity. PLoS One 10: e0122667 https://doi.org/10.1371/journal.pone.0122667.

Gordin S (1980). Milking animals and fermented milks of the Middle East and their contribution to man's welfare. J. Dairy Sci. 63: 1031-1038. https://doi.org/10.3168/jds.S0022-0302(80)83041-4

Goudet J (1995). FSTAT, a program to estimate and test gene diversities and fixation indices (version 2.9.3). Updated from Goudet J, 1995. FSTAT v-1.2. A computer program to calculate F-statistics. J. Hered. 86: 485-486. https://doi. org/10.1093/oxfordjournals.jhered.a111627

Green MR and Sambrook J (2012). Molecular cloning: a laboratory manual (4th edn.). Cold Spring Harbor Laboratory Press, New York.

Hedrick PW (2000). Genetics of Populations. Jones and Bartlett Publishers International, London.

Kim ES, Elbeltagy AR, Aboul-Naga AM, Rischkowsky B, et al. (2016). Multiple genomic signatures of selection in goats and sheep indigenous to a hot arid environment. Heredity (Edinb) 116: 255-264. https://doi.org/10.1038/hdy.2015.94

Leberg PL (2002). Estimating allelic richness: effects of sample size and bottlenecks. Mol. Ecol. 11: 2445-2449. https:// doi.org/10.1046/j.1365-294X.2002.01612.X

Li MH, Zhao SH, Bian C, Wang HS, et al. (2002). Genetic relationships among twelve Chinese indigenous goat populations based on microsatellite analysis. Genet. Sel. Evol. 34: 729-744. https://doi.org/10.1186/1297-9686-34-6-729

Liu X (2010). The silk road in world history. Oxford University Press, New York.

Mavrogenis AP, Antoniades NY and Hooper RW (2006). The Damascus (Shami) goat of Cyprus. Anim. Genet. Res. Inf. 38: 57-65. https://doi.org/10.1017/S1014233900002054

Nei M (1972). Genetic distances between populations. Am. Nat. 106: 283-292. https://doi.org/10.1086/282771

Porter V (2002). Mason's World Dictionary of Livestock Breeds, Types and Varieties. 5th edn. CABI International Publishers. Oxfordshire, UK.

Pritchard JK, Stephens M and Donnelly P (2000). Inference of population structure using multilocus genotype data. Genetics 155: 945-959.

Ridley M (2004). Evolution. 3rd edn. Blackwell Scientific Publishing, Malden.

Tamura K, Peterson D, Peterson N, Stecher G, et al. (2011). MEGA5: molecular evolutionary genetics analysis using maximum likelihood, evolutionary distance, and maximum parsimony methods. Mol. Biol. Evol. 28: 2731-2739. https://doi.org/10.1093/molbev/msr121

Tapio M, Ozerov M, Tapio I, Toro MA, et al. (2010). Microsatellite-based genetic diversity and population structure of domestic sheep in northern Eurasia. BMC Genet. 11: 76. https://doi.org/10.1186/1471-2156-11-76

Taylor PD, Fahrig L, Henein K and Merriam G (1993). Connectivity is a vital element of landscape structure. Oikos 68 : 571-573. https://doi.org/10.2307/3544927

Thilagam K, Ramamoorthi J, Sivaselvam SN, Karthickeyan SMK, et al. (2006). Kanniadu goats of Tamilnadu, India: genetic characterisation through microsatellite markers. Livest. Res. Rural Dev. 18: 149.

Tucho AT (2004). Genetic Characterization of Indigenous Goat Population of Ethiopia Using Microsatellite DNA Markers. PhD. National Dairy Research Institute, Deemed University.

Visser C, Hefer CA, van Marle-Köster E and Kotze A (2004). Genetic variation of three indigenous goat populations in South Africa. S. Afr. J. Anim. Sci. 34: 24-27.

Warmuth VM, Campana MG, Eriksson A, Bower M, et al. (2013). Ancient trade routes shaped the genetic structure of horses in eastern Eurasia. Mol. Ecol. 22: 5340-5351 https://doi.org/10.1111/mec.12491.

Weir BS (1996). Genetic Data Analysis 2: Methods for Discrete Population Genetic Data. 2nd edn. Sinauer Associates Inc., Sunderland.

Genetics and Molecular Research 16 (3): gmr16039701 